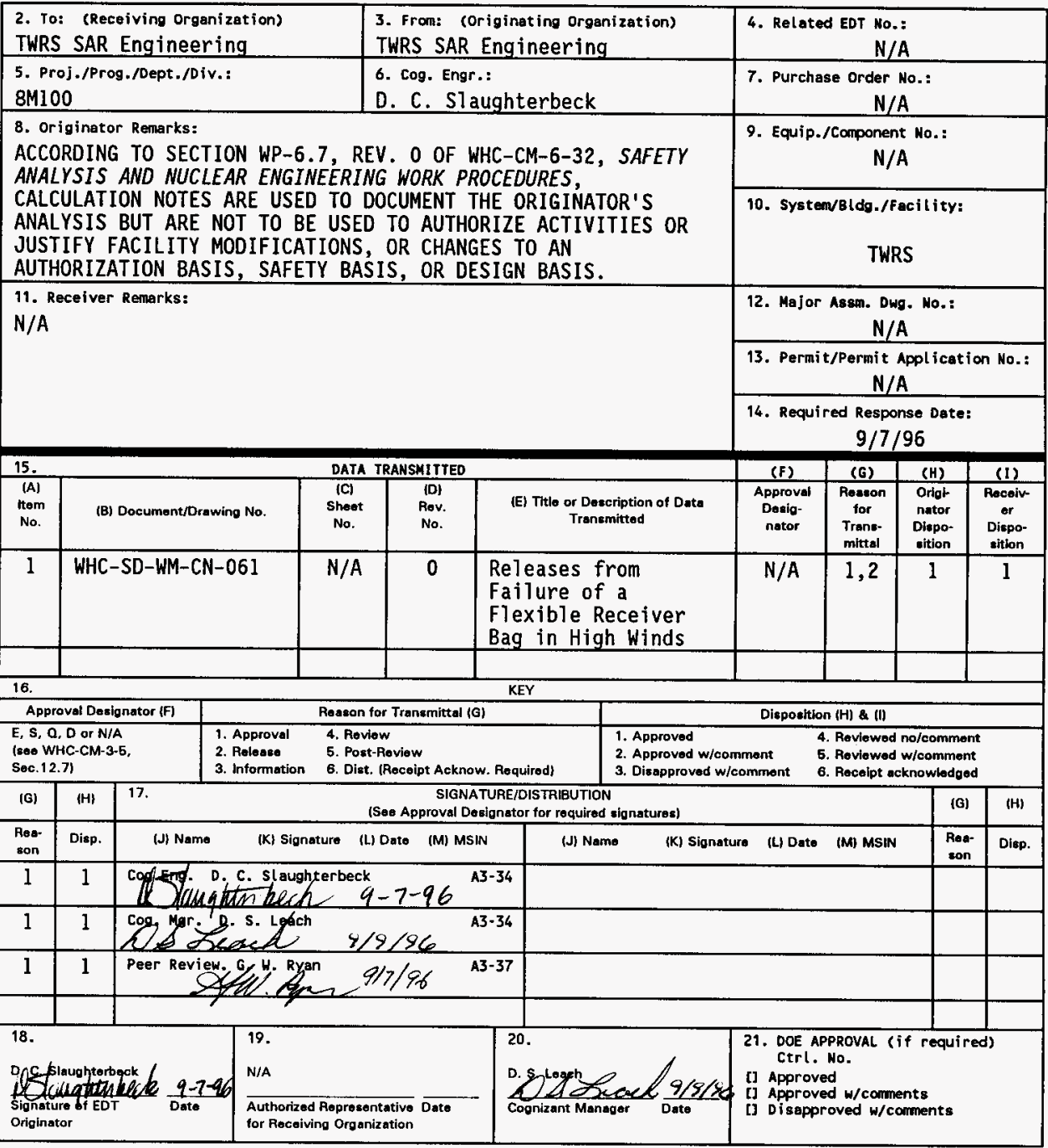




\section{Releases from Failure of a Flexible Receiver Bag in High Winds}

D. C. Slaughterbeck

Westinghouse Hanford Company, Richland, WA 99352

U.S. Department of Energy Contract DE-AC06-87RL10930

EDT/ECN: 614557

Org Code: $8 \mathrm{M} 100$

UC: $\quad 510$

B\&R Code: EW3120071

Charge Code: N1FC3

Total Pages: 28

Key Words: flex receiver, radioactive materials, TWRS, tank farms

Abstract: This document supports the development and presentation of the following accident scenario in the TWRS Final Safety Analysis

Report:

\section{Natural Phenomena - High Wind.}

The calculations needed to quantify the risk associated with this accident scenario are included within.

TRADEMARK DISCLAIMER. Reference herein to any specific comercial product, process, or service by trade name, trademark, manufacturer, or otherwise, does not necessarily constitute or imply its endorsement, recommendation, or favoring by the United States Goverment or any agency thereof or its contractors or subcontractors.

Printed in the United States of America. To obtain copies of this document, contact: WHC/BCS Document Control Services, P.0. Box 1970, Mailstop H6-08, Richland WA 99352, Phone (509) 372-2420; Fax (509) 376-4989.
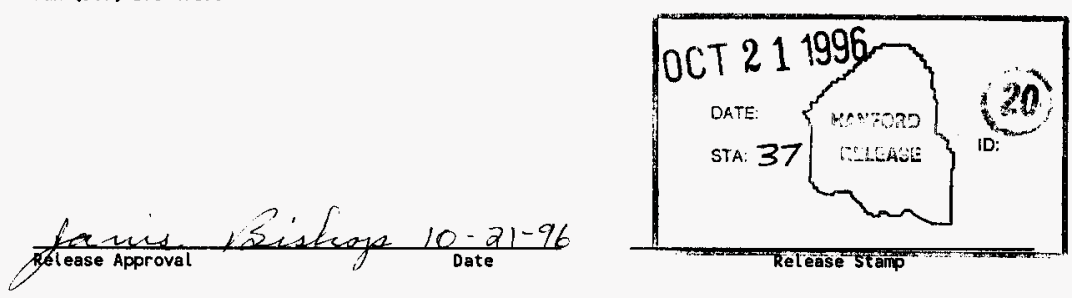

\section{Approved for Public Release}




\title{
RELEASES FROM \\ FAILURE OF A FLEXIBLE RECEIVER BAG IN HIGH WINDS Revision 0
}

\author{
Tank Waste Remediation System \\ Final Safety Analys is Report Project \\ by \\ Safety Analysis \& Nuclear Engineering \\ and \\ Don Slaughterbeck \\ Science Applications International Corporation \\ 545 Shoup Avenue \\ Idaho Falls, Idaho \\ (208) $-528-2101$
}

September 1996

NOTE: According to Section WP-6.7, Rev. 0 of WHC-CM-6-32, Safety Analysis and Nuclear Engineering Work Procedures, Calculation Notes are used to document the originator's analysis but are not to be used to authorize activities or justify facility modifications, or changes to an authorization basis, or design basis. 
WHC-SD-WM-CN-061 REV. 0

This page intentionally left biank.

Page 2 of 27 


\section{CONTENTS}

1.0 Introduction and Purpose

5 of 27

2.0 Analysis Input

6 of 27

3.0 Assumptions

8 of 27

4.0 Analytical Methods

8 of 27

5.0 Radiologica? Dose Calculations

8 of 27

6.0 Toxicological Exposure Calculations

10 of 27

7.0 Analysis Results

11 of 27

8.0 Conclusions

11 of 27

9.0 References

12 of 27

Appendix A-Calculations of Source Term

13 of 27

Appendix B-Calculations of Direct and Skyshine Radiation Doses

18 of 27

Appendix C- Peer Review and HEDOP Review Checklists

26 of 27 


\section{WHC-SD-WM-CN-061 REV. 0}

This page intentionally left blank. 
WHC-SD-WM-CN-061 REV. 0

\section{Failure of a Flexible Receiver Bag in High Winds}

\subsection{Introduction and Purpose}

This calculation note documents the radiological and toxicological consequence analyses of a Flexible Receiver Bag Failure in support of a TWRS FSAR high wind accident considered under Natura? Phenomena. The specifc wind accident in the FSAR is "Flexible Receiver Bag Failure".

\section{Background}

A flexible receiver is an engineered system of components used to wash, contain, transport, and dispose of contaminated equipment upon removal from underground waste storage tanks. The flexible receiver is bolted onto a 4inch or 6-inch tank riser and is supported by four legs with hydraulic control that rest on the surface above the tank dome. The first flexible receiver station above the riser contains a spray ring where high pressure water is used to wash contaminates from the equipment and drain them back to the tank. The equipment is then withdrawn through a pipe spool into a flexible receiver bag that provides containment of the contaminated equipment. The cylindrical receiver bag is initially folded (like an accordion) and then unfolds as the equipment is withdrawn from the tank riser by a crane. The bag is sealed at the top, and as the equipment is withdrawn above the tank riser, the bottom is sealed with a cable and cutters are used to separate the flexible bag from unused bag material. The flexible receiver bag inflates with air from the tank head space that is drawn through the riser and washing station. When used on a tank with an active ventilation system and the tank is under a slight vacuum, the bag tends to collapse around the instrument with a minimum of air inflation. Flexible receiver bags are made of an abrasion-resistent, tear-resistent fabric.

\section{Accident Scenario Development and Description}

This scenario assumes a wind-induced failure of a flexible receiver bag containing contaminated equipment removed from an underground waste storage tank. Failure of the flexible receiver bag is postulated when the equipment

has been withdrawn above the riser and just prior to sealing the bottom. High winds cause the crane and supported equipment to swing and tear or puncture the bag in the area where the bottom seal would be placed. Because the equipment is fully withdrawn, it offers no resistance against the riser, and only moderate resistance by the bag guide rods. The maximum amount of contaminates is present when the equipment is fully withdrawn.

\section{Accident Frequency Development Assuming No Controls.}

During preoperational testing, crane operators report difficultly in precisely positioning a loaded flexible receiver in winds greater than about $32 \mathrm{~km} / \mathrm{h}(20 \mathrm{mph})$. For winds up to $64 \mathrm{~km} / \mathrm{h}(40 \mathrm{mph})$, it is assumed crane 
WHC-SD-WM-CN-06I REV. 0

operators could manage a loaded flexible receiver if necessary. For wind gusts at $97 \mathrm{~km} / \mathrm{hr}(60 \mathrm{mph})$ it is assumed a loaded flexible receiver would be essentially out of control. Therefore, it is assumed that winds gusts of 97 $\mathrm{km} / \mathrm{h}$ (60 mph) are sufficient to cause the flexible receiver to swing and puncture or tear the fabric. Wind gusts are assumed to be a more accurate indicator of accident risk than straight winds. As 1isted in Table 3.4.2.13-1 of the draft FSAR high wind section, such wind gusts occur once every two years. Operations estimate that flexible receivers withdraw equipment no more than 24 days per year. It is conservatively assumed the wind gusts occur at the time the flexible receiver is at risk. Without administrative controls, the joint probability of operating the flexible receiver and having wind velocities of $97 \mathrm{~km} / \mathrm{hr}(60 \mathrm{mph})$ is then

$$
\begin{aligned}
\text { Probability } & =\begin{array}{l}
(1 \text { high wind } / 2 \text { years }) ~(24 \text { days operation } / 365 \text { days per } \\
\text { year })
\end{array} \\
& =\quad 3 \times 10^{-2} \text { occurrences per year (anticipated category) }
\end{aligned}
$$

Assuming administrative controls are in place to restrict crane operations in high winds, and assuming the controls work as intended, the flexible receiver bag failure in high winds is prevented.

\subsection{Analysis Input}

\subsection{Amount of Material Released}

Because of the high pressure washing jets in the lower portion of the flexible receiver, most concentrated tank wastes are removed from the equipment and drained to the tank before the equipment enters the flexible receiver bag. Some surface contaminates remain on the equipment, and the washing jets create aerosols that enter the flexible receiver bag as it inflates with air from the tank headspace. Field readings by operations show radiation levels near the flexible receiver bag are less than about $10 \mathrm{rem} / \mathrm{hr}$. Using this external dose rate, a Microshield calculation (see Appendix A) determined that the equivalent of $11.6 \mathrm{~L}$ of tank waste (aging waste 1iquids) was present in a $9.1 \mathrm{~m}$ section of the flexible receiver bag.

Aging waste tank liquids were assumed because the flexible receiver has been used primarily on aging waste tanks. Note that the consequences are insensitive to the type of waste assumed because fewer liters of a more radioactive waste type would be required to produce $10 \mathrm{R} / \mathrm{hr}$; fewer liters of the more radioactive waste type would result in essentially the same consequences because the release rate mechanisms are linear. Likewise, more liters of a less radioactive waste type would be required to produce $10 \mathrm{R} / \mathrm{hr}$ and again, the resulting consequences would be the same. As discussed below, the wastes are partitioned between the aerosols in the vapor space of the flexible receiver bag and on the internal surfaces of the instrument and bag. 
The inside surfaces of the flexible receiver bag and instrument were assumed to have a water film carrying the $11.6 \mathrm{~L}$ of contaminates. These surfaces were assumed to drain to the ground when the flexible receiver bag was torn or punctured by high winds. High winds would cause aerodynamic entrainment and suspension of the waste from the ground. From DOE Handbook on Airborne Release Fractions/rates and Respirable Fractions for NonReactor Nuclear Facilities (DOE-HDBK-3010-94, Section 3.2.4.5, page 3-42), the bounding airborne release rate (ARR) for suspension of contaminates deposited on soil was $9 \times 10^{-5}$ per hour. The resulting time-dependent source term from the soil was $1.04 \times 10^{-3} \mathrm{~L}$ per hour.

To bound the release from the vapor space inside the flexible receiver, it was assumed that the respirable aerosol content could be no greater than $100 \mathrm{mg} / \mathrm{m}^{3}$ (quasi-stable maximum). Using a bounding mass density of $1 \mathrm{~kg} / \mathrm{L}$, the material at risk in the $2.7 \mathrm{~m}^{3}$ vapor space of the bag was determined to be $2.7 \times 10^{-4} \mathrm{~L}$. Therefore, the resulting source term (puff release) from the vapor space was $2.7 \times 10^{-4} \mathrm{~L}$.

The total source term (both puff and time dependent) for 12 hours (used for onsite exposures) was $1.28 \times 10^{-2} \mathrm{~L}$, and the source term for 24 hours (used for offsite exposures) was $2.52 \times 10^{-2} \mathrm{~L}$.

\subsection{Unit Liter Doses (ULDs) and Sum-of-Fractions}

The ULDs for this analysis are taken from WHC-SD-WM-SARR-037, Rev 0 , Development of Radiological Concentrations and Unit Liter Doses for TWRS FSAR Radiological Consequence Calculations. For Aging Waste Liquids, the Inhalation ULD is $1.4 \mathrm{E} 3 \mathrm{~Sv} / \mathrm{L}$, and the Ingestion ULD is $0.092 \mathrm{~Sv}-\mathrm{m}^{3} / \mathrm{s}-\mathrm{L}$ (see table in Appendix B). Toxicological exposures were calculated consistent with WHC-SD-WM-SARR-011, Rev. 2, Toxic Chemical Considerations for Tank Farm Releases (see table in Appendix B).

\subsection{Dispersion Coefficients $(x / Q)$}

Dispersion coefficients for puff releases:

$$
\begin{array}{ll}
\text { Onsite- } & 3.41 \mathrm{E}-2 \mathrm{~s} / \mathrm{m}^{3} \\
\text { Offsite- } & 2.83 \mathrm{E}-5 \mathrm{~s} / \mathrm{m}^{3}
\end{array}
$$

Dispersion coefficients for continuous releases:

$$
\begin{array}{ll}
\text { Onsite- } & 1.13 \mathrm{E}-2 \mathrm{~s} / \mathrm{m}^{3} \\
\text { Offsite- } & 2.12 \mathrm{E}-5 \mathrm{~s} / \mathrm{m}^{3}
\end{array}
$$

A1) dispersion coefficients were based on WHC-SD-WM-SARR-016 (see tables in Appendix B).

\subsection{Breathing Rate (R)}

Based on WHC-SD-WM-SARR-016, a breathing rate of $3.3 E-4 \mathrm{~m}^{3} / \mathrm{s}$, corresponding to 1 ight physical activity, was used to calculate consequences for all receptors. 
WHC-SD-WM-CN-061 REV. 0

\subsection{Assumptions}

Radiological doses are based on a combined puff release of aerosols from the vapor space of the flexible receiver and a time-dependent release of aerosols from liquids dispersed in soil. The ULDs corresponded to aging waste liquids. Likewise, the sum-of-fractions were based on a combined DST liquid puff (acute) release and a DST liquid time-dependent release. For toxicological calculations, the DST liquids includes constituents of aging waste liquids. The dispersion coefficients $X / Q$ corresponded to the 99.5 percentile with plume meander correction. This is initially very conservative because the accident occurs due to the high wind where dispersion would be much higher. However, high winds would not be expected to persist for the 12 and 24 hour exposure durations for onsite and offsite individuals, respectively.

\subsection{Analytical Methods}

The overall strategy used was to calculate the source term from bounding field radiation readings taken from the flexible receiver bag on contact (non-accident) using Microshield. 7 The resulting source term was partitioned into a vapor space term, and a liquid term that was assumed to drain to the soil after the flexible receiver bag was torn or punctured due to high winds. Radiological doses were then calculated for receptors consistent with WHC-SD-WM-SARR-016, Rev 2, Tank Waste Compositions and Atmospheric Dispersion Coefficients for use in ASA Consequence Assessments, and WHC-SD-WMSARR-037, Rev 0, Development of Radiological Concentrations and Unit Liter Doses for TWRS FSAR Radiological Consequence Calculations. Toxicological exposures were calculated consistent with WHC-SD-WM-SARR-011, Rev. 2, Toxic Chemical Considerations for Tank Farm Releases.

\subsection{Radiological Dose Consequence Analysis}

Calculations of Rad Doses consist of 5 parts:

A. Inhalation of puff,

B. Ingestion of puff,

C. Inhalation of entrained spill,

D. Ingestion of entrained spill, and

E. Direct, skyshine and Bremsstrahllung.

There is an onsite and offsite calculation for these except ingestion does not apply to the onsite receptor.

PART A- Inhalation Dose From Puff

Dose $(S v)=($ Source Term $)(x / Q)$ (Breathing Rate) (ULD)

$=(\mathrm{L})(\mathrm{s} / \mathrm{m} 3)(\mathrm{m} 3 / \mathrm{s})(\mathrm{Sv} / \mathrm{L})$

ONSITE:

$=(2.7 \mathrm{E}-4)(3.41 \mathrm{E}-2)(3.3 \mathrm{E}-4)(1.4 \mathrm{E}+3)$

Page 8 of 27

\footnotetext{
Microshield is a registered trademark of Grove Engineering, Inc.
} 
WHC-SD-WM-CN-061 REV. 0

$=4 \cdot 3 \mathrm{E}-6 \mathrm{SV}$

OFFSITE:

$$
\begin{aligned}
& =(2.7 \mathrm{E}-4)(2.83 \mathrm{E}-5)(3.3 \mathrm{E}-4)(1.4 \mathrm{E}+3) \\
& =3.5 \mathrm{E}-9 \mathrm{SV}
\end{aligned}
$$

PART B- Ingestion Dose From Puff

Dose $(S v)=($ Source Term) $(x / Q)$ (ULD)

$=(L)(s / m 3)(S v-m 3 / s-L)$

OFFSITE:

$$
\begin{aligned}
& =(2.7 \mathrm{E}-4)(2.83 \mathrm{E}-5)(9.2 \mathrm{E}-2) \\
& =7.0 \mathrm{E}-10 \mathrm{SV}
\end{aligned}
$$

PART C - Inhalation Dose From Entrainment

$$
\begin{aligned}
& \text { Dose }=\left(\text { Source Term) (Breathing Rate) }\left(x / Q^{\prime}\right)\right. \text { (Duration) (ULD) } \\
& =(\mathrm{L} / \mathrm{s})(\mathrm{m} 3 / \mathrm{s})(\mathrm{s} / \mathrm{m} 3)(\mathrm{s})(\mathrm{Sv} / \mathrm{L})=\mathrm{SV} \\
& \text { ONSITE: } \\
& \begin{array}{l}
=(1.04 \mathrm{E}-3 / 3600)(3.3 \mathrm{E}-4)(1.13 \mathrm{E}-2)(4.3 \mathrm{E} 4)(1.4 \mathrm{E}+3) \\
=6.5 \mathrm{E}-5 \mathrm{SV}
\end{array} \\
& \begin{array}{l}
=(1.04 \mathrm{E}-3 / 3600)(3.3 \mathrm{E}-4)(2.12 \mathrm{E}-5)(8.6 \mathrm{E} 4)(1.4 \mathrm{E}+3) \\
=2.4 \mathrm{E}-7 \mathrm{SV}
\end{array}
\end{aligned}
$$

PART D- Ingestion Dose From Entrainment

$$
\begin{aligned}
& \text { Dose }=\text { (Source Term) }\left(x / Q^{\prime}\right) \text { (ULD) (Duration) } \\
& =(\mathrm{L} / \mathrm{s})(\mathrm{s} / \mathrm{m} 3)(\mathrm{Sv}-\mathrm{m} 3 / \mathrm{s}-\mathrm{L})(\mathrm{s})=\mathrm{SV} \\
& \begin{array}{l}
=(1.04 \mathrm{E}-3 / 3600)(2.12 \mathrm{E}-5)(9.2 \mathrm{E}-2)(8.6 \mathrm{E} 4) \\
=4.8 \mathrm{E}-8 \mathrm{SV}
\end{array}
\end{aligned}
$$

PART E- Direct, Skyshine and Bremsstrahlung

Direct radiation was calculated with Microshield by modeling the spill as a vertical cylinder $1 \mathrm{~cm}$ high and a diameter of 1.22 meters (attached). The resulting 12 hour dose for onsite exposure was $3.4 \mathrm{mR}$. Offsite exposure is negligible. Microskyshine ${ }^{2}$ was used to calculate the skyshine (attached). The resulting 12 hour dose for onsite exposure was $3.2 \mathrm{mR}$. The offsite exposure is negligible. Bremsstrahlung doses were considered negligible based on similar calculations where they are a factor of 10 smaller than the direct and skyshine doses (e.g. see WHC-SD-WM-CN-004 Rev 0).

ONSITE SUM $=1.4 \mathrm{E}-4 \mathrm{SV}$

OFFSITE SUM $=2.9 \mathrm{E}-7 \mathrm{SV}$

$$
\text { Page } 9 \text { of } 27
$$

Microskyshine is a registered trademark of Grove Engineering, Inc. 
WHC-SD-WM-CN-061 REV. 0

\subsection{Toxicological Exposure Consequence Analysis}

Calculations of toxic exposures consist of 2 parts:

A. Exposure to puff,

B. Exposure to entrained spil1.

There is an onsite and offsite calc for each of these.

PART A- Exposure to puff release

$$
\text { EXPOSURE }=\text { (ULD-anticipated) (Source term) }
$$

$=(1 / L)(L)=$ sum-of-fractions

ONSITE:

$=(2.9 \mathrm{E} 3)(2.7 \mathrm{E}-4)$

$=0.78$

OFFSITE:

$=(3.4 \mathrm{E}-2)(2.7 \mathrm{E}-4)$

$=9 \mathrm{E}-6$

PART B- Exposure to entrainment releases

EXPOSURE = (ULD-anticipated) (Source term rate)

$=(\mathrm{s} / \mathrm{L})(\mathrm{L} / \mathrm{s})=$ sum-of-fractions

ONSITE:

$=(1 E 4) \quad(1.04 E-3 / 3600)$

$=2.9 \mathrm{E}-3$

OFFSITE :

$=(8.4)(1.04 E-3 / 3600)$

$=2.4 \mathrm{E}-6$

TOTAL ONSITE SUM $=0.78$

TOTAL OFFSITE SUM $=1.1 \mathrm{E}-5$ 


\subsection{Analysis Results}

Consequences of a wind-induced failure of the flexible receiver bag are summarized in Table 7-1.

Table 7-1. Consequences of Flexible Receiver Bag Failure.

\begin{tabular}{|c|c|c|c|c|c|}
\hline \multirow[b]{2}{*}{ Receptor/hazard } & \multicolumn{2}{|c|}{ Calculated dose/exposure } & \multicolumn{3}{|c|}{ Evaluation guideline } \\
\hline & Unmitigated & Mitigated & Anticipated & Unlikely & $\begin{array}{c}\text { Extremely } \\
\text { unlikely }\end{array}$ \\
\hline Offsite/radiological & $2.9 \mathrm{E}-4 \mathrm{mSv}$ & a & $5 \mathrm{mSv}$ & $50 \mathrm{mSv}$ & $250 \mathrm{mSv}$ \\
\hline Onsite/radiological & 1.4E-1 mSv & a & $50 \mathrm{mSv}$ & $250 \mathrm{mSv}$ & $1 \mathrm{~Sv}$ \\
\hline $\begin{array}{l}\text { Offsite/toxicological sum-of- } \\
\text { fractions }\end{array}$ & $2.4 \mathrm{E}-6$ & a & 1 & 1 & 1 \\
\hline $\begin{array}{l}\text { Onsite/toxicological sum-of- } \\
\text { fractions }\end{array}$ & 0.78 & a & 1 & 1 & 1 \\
\hline
\end{tabular}

a. The accident is prevented when controls are imposed.

\subsection{Conclusions}

The unmitigated comparisons to risk evaluation guidelines are shown in Table 7-1. In all cases, the radiological and toxicological exposures are below the guidelines. Therefore, neither safety SSCs nor technical safety requirements are required for this accident. 


\subsection{References}

PNL-4622, 1983, Climatological Summary for the Hanford Area, Pacific Northwest Laboratory, Richland, Washington.

DOE-HDBK-3010-94, 1994, Airborne Release Fractions/rates and Respirable Fractions for NonReactor Nuclear Facilities, U. S. Department of Energy, Washington, D. C.

WHC-SD-WM-SARR-011, Rev 2, Toxic Chemical Considerations for Tank Farm Re7eases, 1996, Westinghouse Hanford Company, Richland, Washington.

WHC-SD-WM-SARR-016, Rev 2, Tank Waste Compositions and Atmospheric Dispersion Coefficients for use in ASA Consequence Assessments, 1996, Westinghouse Hanford Company, Richland, Washington.

WHC-SD-WM-SARR-037, Rev 0, Development of Radiological Concentrations and Unit Liter Doses for the TWRS FSAR Radiological Consequence Calculations, Westinghouse Hanford Company, Richland, Washington.

MICROSHIELD Version 4, Grove Engineering, Inc. 15125 Shady Grove Road, Rockville, Maryland, 1992.

MICROSKYSHINE, Grove Engineering, Inc. 15125 Shady Grove Road, Rockville, Maryland, 1987.

WHC-SD-WM-CN-004, Rev 0, Calculation Notes that Support Accident Scenario and Consequence Development for the Subsurface Leak Remaining Subsurface Accident, 1996, Westinghouse Hanford Company, Richland, Washington. 


\section{WHC-SD-WM-CN-061 REV. 0 \\ APPENDIX A \\ Calculations of Source Term}

Microshield was used to back calculate material at risk (MAR) inside flexible receiver bag when instrument is fully withdrawn from tank. Source is assumed liquid aging waste with radionuclide concentrations as in the table on the following page. Calculate unit radiation dose for $1 \mathrm{R} /$ hour and adjust depending on bounding radiation readings from operations.

- Assume 30 feet of instrument exposed to liquid aging waste.

- Assume flexible receiver bag is 2 feet in diameter when inflated.

- Assume unit radiation dose of $1 \mathrm{R} /$ hour at 13 inches from centerline.

- Using the dimensions above, the volume of a fully inflated receiver bag is:

$$
\begin{aligned}
V & =\left(p i D^{2} / 4\right) \quad \text { (height) } \\
& =\left(\mathrm{m}^{2}\right)(\mathrm{m})=\mathrm{m}^{3} \\
& =\left((3.1416)(0.61)^{2} / 4\right)(9.144) \\
& =2.67 \mathrm{~m}^{3}
\end{aligned}
$$

(Note this value agrees with Microshield calculation of $2.6688 \mathrm{E} 6$ cubic centimeters.)

The radionuclide distribution of aging waste, the Microshield calculation, and interpretation follow. 
WHC-SD-WM-CN-061 REV. 0

Table

Radionuclide Concentrations in Tank Waste.

\begin{tabular}{|c|c|c|c|c|c|c|}
\hline \multirow[b]{2}{*}{ Isotope } & \multicolumn{6}{|c|}{ Concentration $(\mathrm{Bq} / \mathrm{l})$} \\
\hline & $\begin{array}{c}\text { SST } \\
\text { 1iquids }\end{array}$ & $\begin{array}{c}55 T \\
\text { solids }\end{array}$ & $\begin{array}{c}\text { DST } \\
\text { liquids }\end{array}$ & $\begin{array}{l}\text { DST } \\
\text { sotids }\end{array}$ & $\begin{array}{c}\text { Aging } \\
\text { waste } \\
\text { Tiquids } \\
\end{array}$ & $\begin{array}{l}\text { Aging } \\
\text { waste } \\
\text { solids }\end{array}$ \\
\hline${ }^{60} \mathrm{CO}$ & $9.53 E+06$ & $4.2 E+08$ & $6.97 E+06$ & $1.5 E+07$ & $7.71 E+05$ & $4.9 E+08$ \\
\hline${ }^{90} \mathrm{Sr}$ & $1.05 \mathrm{E}+10$ & $1.6 \mathrm{E}+12$ & 4.59E+09 & $5.2 E+10$ & $5.60 E+09$ & $2.9 E+12$ \\
\hline${ }^{80}{ }^{8}$ & $1.05 \mathrm{E}+10$ & $1.6 E+12$ & $4.59 E+09$ & $5.2 E+10$ & $5.60 \mathrm{E}+09$ & $2.9 E+12$ \\
\hline${ }^{737} \mathrm{Cs}$ & $2.21 E+10$ & $1.0 E+11$ & $5.86 E+10$ & $5.9 E+10$ & $8.84 E+10$ & $9.8 E+10$ \\
\hline $156 \mathrm{Eu}$ & $2.35 E+09$ & $5.8 \mathrm{E}+09$ & $4.18 \mathrm{E}+07$ & $3.0 E+08$ & 0.00 & 0.00 \\
\hline${ }^{27} \mathrm{~Np}$ & 0.00 & 0.00 & $2.3 E+05$ & $8.1 E+05$ & $9.20 \mathrm{E}+04$ & $9.9 E+08$ \\
\hline${ }^{28} \mathrm{Pu}$ & $9.21 \quad E+04$ & $1.9 \mathrm{E}+08$ & $1.78 \mathrm{E}+06$ & $7.2 E+07$ & $2.75 E+03$ & $6.7 E+07$ \\
\hline${ }^{39} \mathrm{Pu}$ & $3.62 E+07$ & $4.4 E+08$ & $7.65 E+06$ & $1.6 \mathrm{E}+09$ & $1.20 E \div 06$ & $4.4 E+08$ \\
\hline${ }^{241} \mathrm{Pu}$ & $2.57 E+08$ & $3.2 E+09$ & $1.84 E+07$ & $3.8 E+09$ & $3.39 E+05$ & $1.7 E+09$ \\
\hline${ }^{4} \mathrm{Am}$ & $4.23 E+07$ & $2.3 E+08$ & $3.40 \mathrm{E}+07$ & $2.7 E+09$ & $1.10 E+06$ & $1.1 E+10$ \\
\hline${ }^{4} \mathrm{Cm}$ & $4.23 E+05$ & $2.3 E+06$ & $1.22 E+05$ & $1.6 \mathrm{E}+07$ & $1.10 E+04$ & $6.1 E+07$ \\
\hline
\end{tabular}

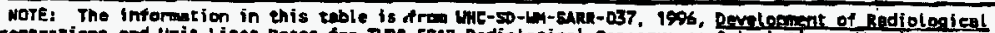

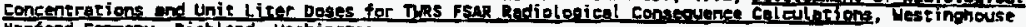
Hanford Coupeny, Richlard, vachindron

DSt = double-shall tank.

SST = sinole-shell rank. 
WHC-SD-WM-CN-061 REV. 0

Kicroshield 3.13

(SATC - 212)

Page : 1
File
Run date: JuExBAG3.MSH
Run time: 2:43 p.m.

File Ref:

Date:

BY:

Checked:

CASE: Radionuclide source term for $1 \mathrm{R} / \mathrm{hr}$ inch from Flex Bag

GEOMETRY 7: Cylindrical source from side - cylindrical shields

Distance to detector...................

Source length.......................... I

Dose point height from base............. Y

Source cylinder radius.................. T1

Thickness of second shield.............. T2

33.020

914.4

91.440

30.480

2.540

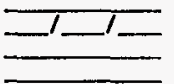

Source Volume: $2.6688 \mathrm{e}+6$ cubic centimeters

MATERIAL DENSITIES ( $\mathrm{g} / \mathrm{Cc})$ :

\begin{tabular}{lrr} 
Material & Source & Shield 2 \\
\hline Air & .001220 & .001220 \\
Aluminum & \\
Carbon & \\
Concrete & \\
Hydrogen & \\
Iron & \\
Lead & \\
Iithium & \\
Nickel & \\
Tin & \\
Titanium & \\
Tungsten \\
Urania \\
Uranium \\
Water \\
Zirconium
\end{tabular}

Page 15 of 27 
WHC-SO-WM-CN-061 KEV. O

Page 2

File: FLEXBAG3.MSH

CASE: Radionuclide source term for $1 \mathrm{k} / \mathrm{hr}$ inch from Flex Bag

BUILDUP FACTOR: based on TAYLOR method.

Using the characteristics of the materials in shield 1 .

INTEGRATION PARAMETERS :

Number of lateral angle segments (Ntheta)..... 11

Number of azimuthal angle segments (Npsi) ...... 11

Number of radial segments (Nradius)........... 11

SOURCE NUCLIDES:

Nuclide
$-A m-241$
Co-60
Np-237
Pu-241

Curies
-3.4500 e- 05
2.4100 e- 05
2.8800 e- 05
1.0600 e- 05

\begin{tabular}{lc} 
Nuclide & Curies \\
\hline $\mathrm{Ba}-137 \mathrm{~m}$ & $2.5600 \mathrm{e}+00$ \\
$\mathrm{Cs}-137$ & $2.7700 \mathrm{e}+00$ \\
$\mathrm{Pu}-238$ & $8.6100 \mathrm{e}-08$ \\
$\mathrm{~S}-90$ & $1.7500 \mathrm{e}-01$
\end{tabular}

\begin{tabular}{lc} 
Nuclide & Curies \\
\hline Cm-244 & 3.4500 e-07 \\
Eu-154 & 0.0000 e+00 \\
Pu-239 & 3.7600 e-05 \\
Y-90 & 1.7500 e-01
\end{tabular}

RESULTS :

\begin{tabular}{|c|c|c|c|c|}
\hline$\underset{f}{\text { Group }}$ & $\begin{array}{l}\text { Energy } \\
\text { (MeV) }\end{array}$ & $\begin{array}{c}\text { Activity } \\
\text { (photons/sec) }\end{array}$ & $\begin{array}{l}\text { Dose point flux } \\
\text { Mev/(sq cm)/sec }\end{array}$ & $\begin{array}{l}\text { Dose rate } \\
(m r / h r)\end{array}$ \\
\hline$-\infty-\infty$ & $--\infty-\infty$ & $-\infty-0--0-0-0$ & -- - & ------- \\
\hline 1 & 1.3359 & $8.917 e+05$ & $1.013 e+01$ & $1.827 e-02$ \\
\hline 2 & 1.1797 & $8.917 e+05$ & $8.944 e+00$ & $1.662 \mathrm{e}-02$ \\
\hline 3 & .6953 & $1.455 e+02$ & $8.626 e-04$ & $1.776 \mathrm{e}-06$ \\
\hline 4 & .6641 & $8.523 e+10$ & $4.830 \mathrm{e}+05$ & $1.001 e+03$ \\
\hline 5 & .2109 & $1.705 e+02$ & $3.094 \mathrm{e}-04$ & $5.784 e-07$ \\
\hline 6 & .1953 & $2.242 \mathrm{e}+02$ & $3.769 e-04$ & $6.908 e-07$ \\
\hline 7 & .1641 & $1.116 \mathrm{e}+03$ & $1.576 \mathrm{e}-03$ & $2.775 e-06$ \\
\hline 8 & .1484 & $7.089 e+02$ & $9.066 e-04$ & $1.560 \mathrm{e}-06$ \\
\hline 9 & .1172 & $8.432 e+02$ & $8.524 e-04$ & $1.345 e-06$ \\
\hline 10 & .1016 & $1.273 \mathrm{e}+03$ & $1.116 e-03$ & $1.682 \mathrm{e}-06$ \\
\hline 11 & & & & \\
\hline 12 & & & & \\
\hline 13 & & & & \\
\hline 14 & & & & \\
\hline 15 & & & & \\
\hline 16 & & & & \\
\hline 17 & & & & \\
\hline 18 & & & & \\
\hline 19 & & & & \\
\hline 20 & & & & \\
\hline & & ---- & $---n---0$ & --- \\
\hline & OTALS: & $8.523 \mathrm{e}+10$ & $4.830 \mathrm{e}+05$ & $1.002 e+03$ \\
\hline
\end{tabular}




$$
\text { WHC-SD-WM-CN-061 REV. } 0
$$

\section{Source Term Results}

The table below illustrates that there is the equivalent of approximately $1.157 \mathrm{~L}$ of aging waste in the 30 feet of exposed flexible receiver bag for each measured $\mathrm{R} /$ hour. From operations, actual radiation readings are less than $10 \mathrm{R}$ per hour, or a source term equivalent of about $11.6 \mathrm{~L}$ of aging waste. Using 9.0E-5 per hour for the airborne release rate (from Mishima, bounding high wind value), and assuming the damage ratio, respirable fraction and leak path factors are all unity, the source rate from the leaked material on the ground is $1.04 \mathrm{E}-3 \mathrm{~L} / \mathrm{hr}$.

Key to Table:

Note: Table based on $1 \mathrm{R} / \mathrm{hr}$

Column 1-Isotopes

Column 2-Radioactive content of liquid aging waste in tank, Bq/L

Column 3-Conversion of tank contents to Curies

Column 4-A back-calculated conversion factor used to check Microshield input values (used only as check)

Column 5-Number of Curies in flexible receiver calculated by Microshield in 30 foot section to yield $1 \mathrm{R} / \mathrm{hr}$.

Column 6-Curies per liter of bag volume (not used)

Column 7 -Liters of liquid aging waste distributed in flexible receiver bag to yield $1 \mathrm{R} / \mathrm{hr}$.

Assume 1 Rem/hr at one inch from flex bag

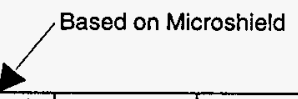

\begin{tabular}{|l|r|r|r|r|r|r|}
\cline { 2 - 7 } \multicolumn{1}{c|}{} & Original $\mathrm{Bq} / \mathrm{L}$ & Original Ci/L & Proportion & $\mathrm{Ci}$ in $30 \mathrm{ft}$ & $\mathrm{Ci} / \mathrm{L}$ in bag & $\mathrm{L}$ of orig \\
\hline $\mathrm{Co}$ & $7.710 \mathrm{E}+05$ & $2.084 \mathrm{E}-05$ & $3.126 \mathrm{E}-11$ & $2.410 \mathrm{E}-05$ & $9.030 \mathrm{E}-09$ & $1.157 \mathrm{E}+00$ \\
$\mathrm{Sr}$ & $5.600 \mathrm{E}+09$ & $1.514 \mathrm{E}-01$ & $3.126 \mathrm{E}-11$ & $1.751 \mathrm{E}-01$ & $6.559 \mathrm{E}-05$ & $1.157 \mathrm{E}+00$ \\
$\mathrm{Y}$ & $5.600 \mathrm{E}+09$ & $1.514 \mathrm{E}-01$ & $3.126 \mathrm{E}-11$ & $1.751 \mathrm{E}-01$ & $6.559 \mathrm{E}-05$ & $1.157 \mathrm{E}+00$ \\
$\mathrm{Cs}$ & $8.840 \mathrm{E}+10$ & $2.389 \mathrm{E}+00$ & $3.126 \mathrm{E}-11$ & $2.763 \mathrm{E}+00$ & $1.035 \mathrm{E}-03$ & $1.157 \mathrm{E}+00$ \\
$\mathrm{~Np}$ & $9.200 \mathrm{E}+04$ & $2.486 \mathrm{E}-06$ & $3.126 \mathrm{E}-11$ & $2.876 \mathrm{E}-06$ & $1.078 \mathrm{E}-09$ & $1.157 \mathrm{E}+00$ \\
$\mathrm{Pu}^{*}$ & $2.750 \mathrm{E}+03$ & $7.432 \mathrm{E}-08$ & $3.126 \mathrm{E}-11$ & $8.597 \mathrm{E}-08$ & $3.221 \mathrm{E}-11$ & $1.157 \mathrm{E}+00$ \\
$\mathrm{Pu}^{*}$ & $1.200 \mathrm{E}+06$ & $3.243 \mathrm{E}-05$ & $3.126 \mathrm{E}-11$ & $3.751 \mathrm{E}-05$ & $1.405 \mathrm{E}-08$ & $1.157 \mathrm{E}+00$ \\
$\mathrm{Pu}^{*}$ & $3.390 \mathrm{E}+05$ & $9.162 \mathrm{E}-06$ & $3.126 \mathrm{E}-11$ & $1.060 \mathrm{E}-05$ & $3.970 \mathrm{E}-09$ & $1.157 \mathrm{E}+00$ \\
$\mathrm{Am}$ & $1.100 \mathrm{E}+06$ & $2.973 \mathrm{E}-05$ & $3.126 \mathrm{E}-11$ & $3.439 \mathrm{E}-05$ & $1.288 \mathrm{E}-08$ & $1.157 \mathrm{E}+00$ \\
$\mathrm{Cm}$ & $1.100 \mathrm{E}+04$ & $2.973 \mathrm{E}-07$ & $3.126 \mathrm{E}-11$ & $3.439 \mathrm{E}-07$ & $1.288 \mathrm{E}-10$ & $1.157 \mathrm{E}+00$ \\
\hline
\end{tabular}

* Pu isotopes (top to bottom) are 238,239, and 241 . 
WHC-SD-WM-CN-061 REV. 0

\section{APPENDIX B}

\section{Calculations of Direct and Skyshine Radiation Doses}

This appendix lists the following:

Table of Unit Liter Doses for Radiological Doses

Tables of Atmospheric Diffusion Coefficients

Table of Sum-of-Fraction Guidelines for Toxicological Exposures

MICROSHIELD input and output for direct radiation.

MICROSKYSHINE input and output for skyshine radiation.

Unit Liter Doses for Inhaiation and Ingestion.

\begin{tabular}{|c|c|c|}
\hline Composite & $\begin{array}{c}\text { Inhalation ULD } \\
(S V / L)\end{array}$ & $\begin{array}{c}\text { Ingestion ULD } \\
\left(S v-m^{3} / s-L\right)\end{array}$ \\
\hline Single-shell tank liquids & $1.1 E+04$ & 0.052 \\
\hline Single-shell tank solids & $2.2 E+05$ & 4.1 \\
\hline Double-shell tank liquids & $6.1 E+03$ & 0.058 \\
\hline Double-shell tank solids & $5.3 E+05$ & 0.48 \\
\hline Aging waste facility liquids & $1.4 \mathrm{E}+03$ & 0.092 \\
\hline Aging waste facility solids & $1.7 E+06$ & 8.1 \\
\hline
\end{tabular}

Page 18 of 27 
Centerline Atmospheric Dispersion Coefficients for 200-Area Tank Farm Acuto Polease to $100-m$ Onsite Recentor located in porct Sector.

\begin{tabular}{|c|c|c|c|}
\hline Meteorological condition & $\begin{array}{l}\text { Integrated } \\
x / Q^{\prime}\left(\mathrm{s} / \mathrm{m}^{3}\right)\end{array}$ & $\begin{array}{l}\text { Integrated } \\
x / Q^{\circ}\left(\mathrm{s} / \mathrm{m}^{3}\right) \\
\text { with } \mathrm{PM}^{2}\end{array}$ & $\begin{array}{l}\text { Maximum puff } \\
x^{\prime} / Q\left(1 / \mathrm{m}^{3}\right)\end{array}$ \\
\hline $\begin{array}{l}99.5 \text { percentile } \\
\text { (bounding) }\end{array}$ & $\begin{array}{l}3,41602 \\
E 100 \mathrm{~m}\end{array}$ & $\begin{array}{l}1.13 \mathrm{E}-02 \\
\text { ESE } 100 \mathrm{~m}\end{array}$ & $\begin{array}{l}9.85 \mathrm{E}-03 \\
\mathrm{E} 100 \mathrm{~m}\end{array}$ \\
\hline Annual Average & $\begin{array}{c}1.20 E-02 \\
N 100 \mathrm{~m}\end{array}$ & $\begin{array}{l}3.80 \mathrm{E}-03 \\
\mathrm{~N} 100 \mathrm{~m}\end{array}$ & NA \\
\hline 50 percentre & $\begin{array}{l}5,33, \mathrm{E}, 03 \\
\mathrm{~N} 100 \mathrm{~m}\end{array}$ & $\begin{array}{c}2,27,6.03 \\
N 100 \text { o }\end{array}$ & $\begin{array}{l}9,48,001 \\
\text { C } 100 \mathrm{~m}\end{array}$ \\
\hline
\end{tabular}

"NRC Regulatory Guide 1.145 (NRC 1982) plume meander correction applied.

Centerline Atmospheric Dispersion Coefficients for 200-Area Tank Farm Acute Release to Site Boundary Receptor Located in Worst Sector.

\begin{tabular}{|c|c|c|c|}
\hline Meteorological condition & $\begin{array}{l}\text { Integrated } \\
x / 0^{\prime}\left(\mathrm{s} / \mathrm{m}^{3}\right)\end{array}$ & $\begin{array}{c}\text { Integrated } \\
x / 0^{\circ}\left(5 / \mathrm{m}^{3}\right) \\
\text { with } \mathrm{PM} \mathrm{M}^{3}\end{array}$ & $\begin{array}{l}\text { Maximum puff } \\
x / Q\left(1 / \mathrm{ml}^{3}\right)\end{array}$ \\
\hline $\begin{array}{l}99.5 \text { Percentile } \\
\text { (bounding) }\end{array}$ & $\begin{array}{l}283,605 \\
18.70 \%\end{array}$ & $\begin{array}{l}212,0.05 \\
18.760 \mathrm{~m}\end{array}$ & $\begin{array}{c}1.14 \mathrm{E}-07 \\
\text { NNW } 8.690 \mathrm{~m}\end{array}$ \\
\hline Annual average & 105.760 . म & N $82760 \%$ & NA \\
\hline 50 pencent $17 \mathrm{e}$ & $\begin{array}{l}443.606 \\
8.760 \%\end{array}$ & $\begin{array}{l}379 . \mathrm{C} \\
\mathrm{N} 8\end{array}$ & $\begin{array}{l}1.02 \mathrm{E}-08 \\
\mathrm{~N} 8.760 \mathrm{~m}\end{array}$ \\
\hline
\end{tabular}
applied.

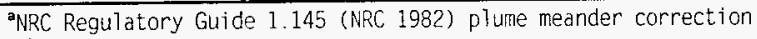

Population Weighted Atmospheric Dispersion Coefficients for 200-Area Tank Farm Acute Release to 50-Mile Population Located in worst Sector.

\begin{tabular}{|c|c|}
\hline Meteorological condition & $\begin{array}{c}\text { Integrated } x / 0^{\prime} \\
(\text { person-s/m }\end{array}$ \\
\hline $\begin{array}{l}99.5 \text { Percentile } \\
\text { (bounding) }\end{array}$ & $\begin{array}{l}4.86 E-02 \\
\text { SE } p 0 p=114.734\end{array}$ \\
\hline Annual average & $\begin{array}{c}1.25 E-02 \\
S E \text { pop }=114734 \\
\end{array}$ \\
\hline 50 percentile & SE.05 pOp $=114.734$ \\
\hline
\end{tabular}




\section{Surn-of-Fraction of Risk Guidelines for a Init Release of Chemicals and Gases. (3 sheets)}

*The sum of fractions are multiplied by the release rate for continuous release and release amount for a puff releases. Release rates for continuous releases are in units of liters per second for liquids and solids, and $\mathrm{m}^{3} / \mathrm{s}$ for gases. Puff release quantities are in units of liters for solids and liquids and $\mathrm{m}^{3}$ for gases.

\begin{tabular}{|c|c|c|c|c|}
\hline \multirow{2}{*}{$\begin{array}{l}\text { Tank waste type (Units of } \\
\text { sum of fractions follow } \\
\text { tank waste type) }\end{array}$} & \multirow{2}{*}{$\begin{array}{c}\text { Maximum } \\
\text { individual }\end{array}$} & \multicolumn{3}{|c|}{ Accident frequency. } \\
\hline & & $1-10^{-2}$ & $10^{-2}-10^{-4}$ & $10^{-4}-10^{-5}$ \\
\hline \multicolumn{5}{|c|}{ DST or SST solid or liquid continuous release } \\
\hline Single-shell liquids $(\mathrm{S} / \mathrm{L})$ & Onsite & $9.6 E+03$ & $7.5 E+02$ & $2.0 E+02$ \\
\hline Single-shel] liquids(s/L) & Offsite & $8.06+00$ & $8.0 .8+00$ & 6.260 \\
\hline Single-shell solids $(\mathrm{s} / \mathrm{L})$ & Onsite & $4068+04$ & $2.1 .6+04$ & $1.0 .6+00$ \\
\hline Single-shell soirds (s/L) & Offsite & $946+01$ & $3.3 \times+6$ & 17 E+0\% \\
\hline Double-shel1 7 iquids (s/L) & Onsite & $1.0 E+04$ & $7.5 E+02$ & $2.1 E+02$ \\
\hline Double-shell liquids(s/L) & Offsite & $8.4 \mathrm{E}+00$ & $8.4 .6+00$ & 621.11 \\
\hline Double-shell solids $(\mathrm{s} / \mathrm{L})$ & Onsite & $1.8 \mathrm{E} 04$ & $3.3 .+80$ & $6.3 \mathrm{\varepsilon}+62$ \\
\hline Double-shell solids(s/L) & Offsite & $1.96 \% 0 \%$ & $1.5 \mathrm{E} 01$ & $28 \mathrm{E}+00$ \\
\hline \multicolumn{5}{|c|}{ DST or SST liquid or solid puff release } \\
\hline Single-she17 liquids $\left(\mathrm{L}^{-1}\right)$ & Onsite & $2.8 E+03$ & $2.2 E+02$ & $5.7 E+01$ \\
\hline Single-shell liquids $\left(\mathrm{L}^{-1}\right)$ & Offsite & $32 \mathrm{EO} 2$ & 32.02 & $25 \mathrm{cos}$ \\
\hline Single-shell solids $\left(\mathrm{L}^{-1}\right)$ & Ons: & $12 \mathrm{ErOM}$ & $6.0 E+03$ & $2.9 E+02$ \\
\hline Single-shell solids $\left(\mathrm{L}^{-1}\right)$ & Offisite & 3.8801 & 13 EO O & $6.9 \mathrm{E} 02$ \\
\hline Double-shell liquids $\left(L^{-1}\right)$ & Onsite & $2.9 E+03$ & $2.2 E+02$ & $6.0 E+01$ \\
\hline Doubie-she11 liquids $\left(L^{-1}\right)$ & offsite & $34.6-12$ & 3.4002 & $2.5 \mathrm{e}-\mathrm{as}$ \\
\hline Double-snell solids $\left(\mathrm{L}^{-1}\right)$ & Onsite & $5.2 \mathrm{E} 93$ & 978612 & $18.6+12$ \\
\hline Double-shell solids $\left(\mathrm{L}^{-1}\right)$ & Onsite & 778.91 & 59802 & 1.1602 \\
\hline \multicolumn{5}{|c|}{ Elammable gas watch list-compesite } \\
\hline Gontinuous Release (s/t) & Ensite & $1.3-E+04$ & $11-1+93$ & $2.6 E+92$ \\
\hline Sont inuus Release (sft) & Offsite & $1.4 .5+01$ & $7.2 E+9$ & $6.1 . E-81$ \\
\hline 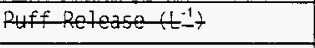 & Onsite & $3.75-03$ & $3.2 E+92$ & $77 E+01$ \\
\hline Ruff Release (t:-1) & Offsite & $24 \leq-82$ & 1.7 .02 & $1.4 E 03$ \\
\hline
\end{tabular}




\section{WHC-SD-WM-CN-061 REV. 0}

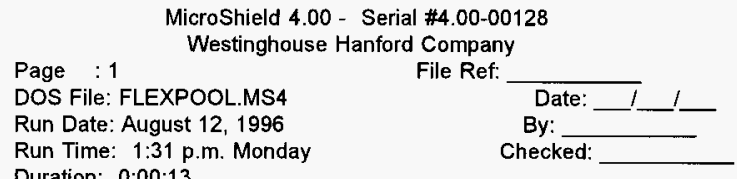

Duration: $0: 00: 13$

Case Title: Flex Bag Spill - Pool $1 \mathrm{~cm}$ Deep

GEOMETRY 7 - Cylinder Volume - Side Shields centimeters feet and inches

Dose point coordinate $X: \quad \begin{array}{lll}10000.0 & 328.0 & 1.0\end{array}$

Dose point coordinate $Y: \quad \begin{array}{lll}150.0 & 4.0 & 11.1\end{array}$

$\begin{array}{lllll}\text { Dose point coordinate } Z: & 0.0 & 0.0 & .0\end{array}$

$\begin{array}{llll}\text { Cylinder height: } & 1.0 & 0.0 & .4\end{array}$

Cylinder radius: $\quad \begin{array}{lll}122.0 & 4.0 & .0\end{array}$

Air Gap: $\quad 9878.0 \quad 324.0 \quad 1.0$

Source Volume: $46759.5 \mathrm{~cm}^{\wedge} 3 \quad 1.65129 \mathrm{cu} \mathrm{ft} . \quad 2853.44 \mathrm{cu}$ in.

\begin{tabular}{lcccc} 
& \multicolumn{3}{c}{ MATERIAL DENSITIES $\left(\mathrm{g} / \mathrm{cm}^{\wedge} 3\right)$} \\
Material & \multicolumn{2}{c}{$\begin{array}{c}\text { Source } \\
\text { Shield }\end{array}$} & $\begin{array}{c}\text { Transition } \\
\text { Shield }\end{array}$ & $\begin{array}{c}\text { Air Gap Immersion } \\
\text { Shield }\end{array}$ \\
Air & & 0.00122 & 0.00122 & 0.00122 \\
Water & 1.0 & & &
\end{tabular}

BUILDUP

Method: Buildup Factor Tables

The material reference is Transition

\begin{tabular}{lc}
\multicolumn{2}{c}{ INTEGRATION PARAMETERS } \\
Quadrature Order \\
Radial & 16 \\
Circumferential & 16 \\
Axial (along Z) & 16
\end{tabular}


WHC-SD-WM-CN-061 REV. 0

SOURCE NUCLIDES

Nuclide curies $\mu \mathrm{Ci} / \mathrm{cm}^{\wedge} 3$ Nuclide curies $\mu \mathrm{Ci} / \mathrm{cm}^{\wedge} 3$

Ba-137m 2.6205e+001 5.6042e+002 Cs-137 2.7701e+001 $5.9241 \mathrm{e}+002$

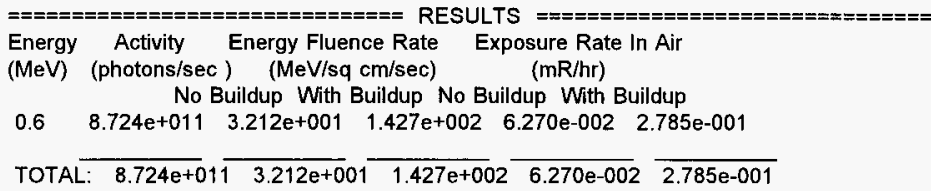




\section{WHC-SD-WM-CN-061 REV. 0}

\section{INTEGRATION PARAMETERS:}

Number of Radial Segments.....................M

Number of Circumferential Segments............N 5

Number of Vertical Segments................... 5

Quadrature Order........................... 16

MATERIAL DENSITIES (g/cc):

Ambient air: .0012

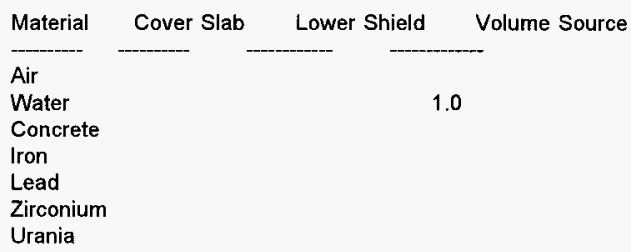

Buildup factor based on: AIR. 
WHC-SD-WM-CN-061 REV. 0

Page 2

CASE: Flex Bag - Poof $1 \mathrm{~cm}$ Deep

SOURCE NUCLIDES:

\begin{tabular}{lllll} 
Nuclide & Curies & \multicolumn{2}{c}{ Nuclide } & \multicolumn{2}{l}{ Curies } \\
\hline Ba-137m & $2.6205 \mathrm{e}+01$ & & Cs-137 & $2.7701 \mathrm{e}+01$
\end{tabular}

RESULTS:

Group Energy Activity Dose point Dose rate

\# (mev) (photons $/ \mathrm{sec}$ ) rads/photon (mr/hr)

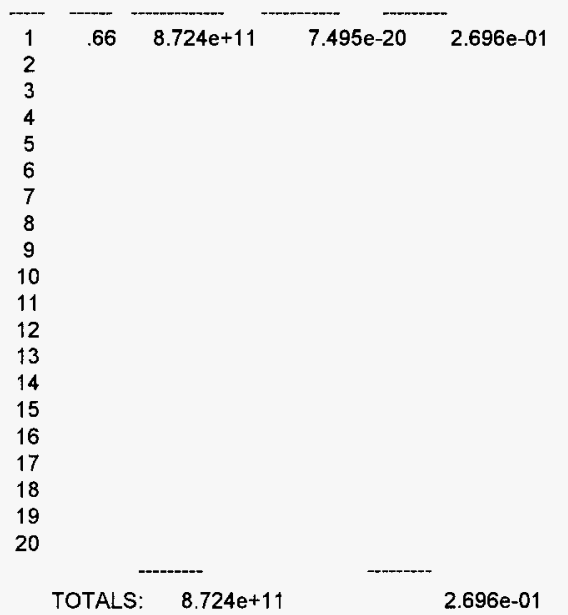

Page 25 of 27 


\section{CHECXLIST FOR PEER REVIEW}

Document Reviewed: WHC-SD-WM-CN-061, Rev. 0, Flexible Receiver Bag Failure in High Winds.

Scope of Review: Entire document.

$\frac{\text { Yes No NA }}{[X][][]}$ *

$\begin{array}{llll}{[X]} & {[} & {[} & {[} \\ {[X]} & {[} & {[} & ] \\ {[x]} & {[} & {[} & ] \\ {[X]} & {[} & {[} & ] \\ {[X]} & {[} & {[} & ] \\ {[x]} & {[} & {[} & {[}\end{array}$

$[X][][]$

[ ] $[$ ] $[\mathrm{X}]$

[x] [ ] [ ]

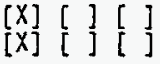

$[x][][]$

$\left[\begin{array}{l}X] \\ {[X]}\end{array}\right][][]$

[X] [ ] [ ]

[X] [ ] [ ]

[ ] [X] * Review calculations, comments, and/or notes are attached.

$[\mathrm{X}][\mathrm{]}] \mathrm{C}$

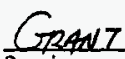

Reviewer

Previous reviews complete and cover analysis, up to scope of this review, with no gaps.

Problem completely defined.

Accident scenarios developed in a clear and logical manner. Necessary assumptions explicitly stated and supported.

Computer codes and data files documented.

Data used in calculations explicitiy stated in document.

Data checked for consistency with original source information as applicable.

Mathematical derivations checked including dimensional consistency of results.

Models appropriate and used within range of validity or use outside range of established validity justified.

Hand calculations checked for errors. Spreadsheet results should be treated exactly the same as hand calculations. Software input correct and consistent with document reviewed. Software output consistent with input and with results reported in document reviewed.

Limits/criteria/guidelines applied to analysis results are appropriate and referenced. Limits/criteria/guidelines checked against references.

Safety margins consistent with good engineering practices. Conclusions consistent with analytical results and applicable limits. Results and conclusions address all points required in the problem statement.

Format consistent with appropriate NRC Regulatory Guide or other standards

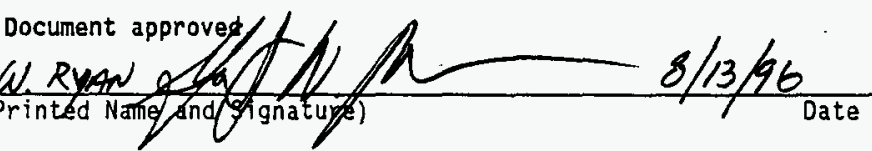

* Any calculations, comments, or notes generated as part of this review should be signed, dated and attached to this checklist. Such material should be labeled and recorded in such a manner as to be intelligible to a technically qualified third party. 


\section{WHC-SD-WM-CN-061 REV. 0 \\ HEDOP REVIEW CHECKLIST \\ for \\ Radiological and Nonradiological Release Calculations}

Document reviewed (include title or description of caiculation, document number, author, and date, as applicable):

WHC-SD-WM-CN-061, Rev. 0, Flexib7e Receiver Bag Failure in High Winds.

Submitted by: Don Slaughterbeck Date Submitted: 8/13/96

Scope of Review: Radiological Dose and Toxicological Exposure Calculations.

YES NO* N/A

A [ ] [ ] 1. A detailed technical review and approval of the environmental transport and dose calculation portion of the analysis has been performed and documented.

tx [ $]$ [ ] 2. Detailed technical review(s) and approval(s) of scenario and release determinations have been performed and documented.

[ ] [ ] [ 3. HEDOP-approved code(s) were used.

[ ] [ ] $\$ 4. Receptor locations were selected according to HEDOP recommendations.

EA [ ] [ ] 5. Ali applicable environmental pathways and code options were included and are appropriate for the calculations.

$\infty$ [ ] [ [ 6. Hanford site data were used.

[] [ ] $\bowtie$ 7. Model adjustments external to the computer program were justified and performed correctly.

$\triangle$ [ ] [ ] 8. The anaiysis is consistent with HEDOP recommendations.

[1 9. Supporting notes, calculations, comments, comment resolutions, or other information is attached. (Use the "Page 1 of $X "$ page numbering format and sign and date each added page.)

(1) [ ] 10. Approval is granted on behalf of the Hanford Environmental Dose Overview Panel.

* All "NO" responses must be explained and use of nonstandard methods justified.

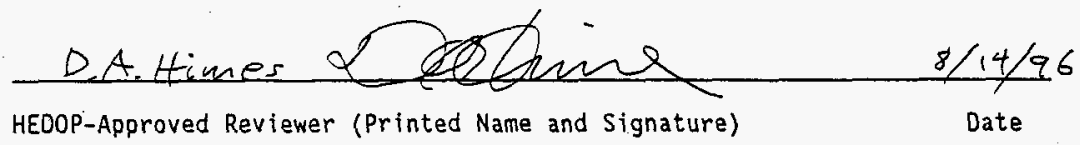

COMMENTS (add additional signed and dated pages if necessary):

Page 27 of 27 


\begin{tabular}{|c|c|c|c|c|c|}
\hline \multicolumn{6}{|c|}{ DISTRIBUTION SHEET } \\
\hline To & \multirow{2}{*}{\multicolumn{3}{|c|}{$\begin{array}{l}\text { From } \\
\text { D. C. Slaughterbeck }\end{array}$}} & \multicolumn{2}{|l|}{ Page 1 of 1} \\
\hline Distribution & & & & \multicolumn{2}{|l|}{ Date $9 / 7 / 96$} \\
\hline \multicolumn{4}{|l|}{ Project Title/Work Order } & \multicolumn{2}{|c|}{ EDT No. 614557} \\
\hline \multicolumn{4}{|c|}{$\begin{array}{l}\text { Releases from Failure of a Flexible Receiver Bag in High Winds, } \\
\text { WHC-SD-WM-CN-061, Rev. } 0\end{array}$} & \multicolumn{2}{|l|}{ ECN No. $\quad N / A$} \\
\hline Name & MSIN & $\begin{array}{c}\text { Text } \\
\text { With All } \\
\text { Attach. }\end{array}$ & Text Only & $\begin{array}{l}\text { Attach./ } \\
\text { Appendix } \\
\text { Only }\end{array}$ & $\begin{array}{l}\text { EDT/ECN } \\
\text { Only }\end{array}$ \\
\hline $\begin{array}{l}\text { E. R. Bruschi } \\
\text { C. Carro } \\
\text { D. S. Leach } \\
\text { TWRS S \& L Project Files (6) } \\
\text { G. W. Ryan (3) } \\
\text { D. C. Slaughterbeck } \\
\text { Central Files (Original }+1 \text { ) }\end{array}$ & $\begin{array}{l}\text { A2-34 } \\
\text { A2-34 } \\
\text { A3-34 } \\
\text { A2-26 } \\
\text { A3-37 } \\
\text { A3-34 } \\
\text { A3-88 }\end{array}$ & $\begin{array}{l}x \\
x \\
x \\
x \\
x \\
x \\
x\end{array}$ & & & \\
\hline
\end{tabular}

